\title{
Modernity as Crisis: Goeng Si and Vampires in Hong Kong Cinema (translation into Russian) ${ }^{1}$
}

\section{Dale Hudson}

New York University Abu Dhabi. Abu Dhabi, United Arab Emirates. Email: dmh2018[at]nyu.edu

\section{Abstract}

This article is a translation of a chapter from the collective monograph Draculas, vampires, and other undead forms: essays on gender, race, and culture, edited by John Edgar Browning and Caroline Joan (Kay) Picart (2009, Scarecrow Press). The author analyzes the question of how Hong Kong cinema responds to the complex situation of Hong Kong's transition from its status as a British territory on loan to a special territory with extended autonomy within the PRC. As a marker pointing to the crisis development of this process, the Chinese people's particular ideas about the so-called "goeng si" ("jumping corpses") were chosen. These revived corpses move in a peculiar jumping way, due to which they received this name. According to the author, in the images of these creatures, as well as in the cinematic vampires that have become an integral part of films made by Hong Kong studios, all the contradictions of the cultural and political situation in Hong Kong are manifested as in a mirror. Despite the fact that Hong Kong was able to actively oppose the global cinema represented by Hollywood, it had to adjust to the global cinematic trends in which vampires played an important role. All of this led to a certain hybridity of images that combined both Western and Chinese traits.

Keywords

Goeng Si; "Chinese Hopping Vampire"; Hong Kong; Cinema; Crisis; Transition; Vampire Films

This work is licensed under a Creative Commons «Attribution» 4.0 International License

1 We are grateful to the author and publishers for permission to translate and publish the chapter of Hudson, D. (2009). Modernity as Crisis: Goeng Si and Vampires in Hong Kong Cinema. In J. E. Browning \& C. J. S. Picart (Eds.), Draculas, Vampires, and Other Undead Forms: Essays on Gender, Race, and Culture. Lanham, Maryland, Toronto, New York, Plymouth, UK: The Scarecrow Press, Inc. 


\title{
Модерность как кризис: кён-си и вампиры в гонконгском кино (перевод на русский) ${ }^{1}$
}

\author{
Хадсон Дейл ${ }^{2}$ \\ Нью-Йоркский университет в Абу-Даби. Абу-Даби, ОАЭ. Email: dmh2018[at]nyu.edu
}

\section{Аннотация}

Данная статья представляет собой перевод главы из коллективной монографии «Draculas, vampires, and other undead forms: essays on gender, race, and culture» вышедшей в 2009 г. под общей редакцией John Edgar Browning и Caroline Joan (Kay) Picart в издательстве Scarecrow Press. Автор анализирует вопрос о том, как гонконгский кинематограф реагирует на сложную ситуацию перехода Гонконга от статуса Британской территории, взятой в аренду, в особую территорию с расширенной автономией в составе КНР. В качестве маркера, указывающего на кризисное развитие этого процесса, был выбраны особые представления китайцев о так называемых «кён си» («прыгающих трупах»). Эти ожившие мертвецы передвигаются прыжками, за что и получили это название. По мнению автора, в образах этих существ, а также в кинематографических вампирах, ставших неотъемлемой частью фильмов, снятых на Гонконгских студиях, как в зеркале проявились все противоречия культурной и политической ситуации в Гонконге. Несмотря на то, что Гонконг смог достаточно активно противопоставить себя глобальному кино, представленному Голливудом, ему пришлось подстраиваться под мировые кинематографические тенденции, в которых образы вампиров играли важную роль. Все это приводило к определенной гибридности образов, в которых сочетались как западные, так и китайские черты.

\section{Ключевые слова}

кён-си; «китайский прыгающий вампир»; Гонконг; кинематограф; кризис; переходный период; фильмы о вампирах

Это произведение доступно по лицензии Creative Commons «Attribution» («Атрибуция») 4.0 Всемирная

1 Редакция выражает признательность автору и издателям за разрешение на перевод и публикацию главы Hudson, D. (2009). Modernity as Crisis: Goeng Si and Vampires in Hong Kong Cinema.

In J. E. Browning \& C. J. S. Picart (Eds.), Draculas, Vampires, and Other Undead Forms: Essays on Gender, Race and Culture. Lanham, Maryland, Toronto, New York, Plymouth, UK: The Scarecrow Press, Inc.

2 Автор благодарит Кэтрин Португез, Анну Сикко, Сару Лоалл, Сунайну Майру и Шитал Маджитию за комментарии и замечания относительно этой главы. 


\section{Введение}

Хит Рики Лау 1985 г. «Goeng si sin sang» (он же «Мистер Вампир») положил начало циклу фильмов «Goeng si» (Трупное окоченение), в котором сочетались традиции боевых искусств, комедии и ужасов гонконгских, голливудских, японских, британских и иных кинокомпаний. Опираясь на китайские литературные и оперные традиции, а также на международные кинематографические конвенции, можно сказать, что кён-си - это транскультурная фигура, ставшая известной в англоязычном мире как «китайский прыгающий вампир» ${ }^{1}$. Фильмы о кён-си ${ }^{2}$ стали новой «изюминкой» гонконгского кинематографа, превратившись в экспортный товар как для регионального, так и глобального, потребления. И хотя в конце 1980-х гг. эта тематика сходит на нет, однако, появился ряд фильмов, в которых отображается взаимодействие, а иногда и соперничество кён-си, с Дракула-подобным вампиром из европейского/голливудского кино.

Целью данной работы является рассмотрение некоторых из этих фильмов в контексте кризиса модерности в Гонконге, предваряющего после 150-летней колониальной истории переход Гонконга в будущие 50 лет в качестве Специального административного района (САР) Китайской Народной Республики (КНР), а также в рамках процесса глобализации, наступивших после холодной войны. В частности, Эстер М. К. Чун и Чу Ю-Вай определяют две модели кинематографического выражения кризисных видений в гонконгском кино, которые я бы хотел рассмотреть в связи с фильмами «Вампир против вампира» (Yi mei dao ren/Однобровый священник, Гонконг 1989; реж. Лам Чин-Ин), «Укус любви» (Jat aau О.К./Один укус, О.К., Гонконг 1990; реж. Стивен Шин) и «Доктор Вампир» (Goeng si ji sang, Гонконг 1991; реж. Джейми Лук): «кризисные эмоции» ностальгии, страха и отчаяния в связи с начавшейся дискуссией о передаче власти, а также «кризисную телесность», связанную с Гонконгом как изменчивым культурным пространством, подвергшимся быстрым трансформациям (Cheung \& Chu, 2004, p. xxviii). Хотя кассовые сборы этих фильмов меркли по сравнению со сборами «Мистера Вампира» и его официальных и

1 Лингвист Катарина М. Уилсон отмечает, что «хотя поверье о вампиризме вероятно возникло в Восточной Европе, слово вампир (для которого славянские языки использовали «упырь»), используемое сейчас повсеместно для описания этого явления, похоже, приобрело популярность именно на Западе». «Повсеместно», однако, в ее исследования относится к Западу, а именно Англии, Франции и Германии восемнадцатого и девятнадцатого веков. (Wilson, 1998, p. 9) В отличие от европейских языков, термин «вампир» не получил широкого распространения в китайских языках. Термин «кён-си» (или «цзянши») переводится буквально как «неподвижный труп» или «неактивная плоть». Термин «kap hyut gwai» («xi xie gui» на пиньинь) часто переводится как «кровососущий призрак», хотя он реже используется по отношению к фильмам, которые мы будем рассматривать в этой работе.

2 Хотя автор часто использует слово «вампир» как синоним кён-си, хотелось бы отметить определенную схожесть этого явления с зомби. Несмотря на то, что они, подобно вампиру, могут высасывать жизненную силу из своих жертв, кён-си - это обобщающий термин для нескольких видов оживших мертвецов. Именно поэтому редакция и решила дать этот материал в специальный номер по зомби, хоть автор и использует термин «вампир» (прим. переводчика) 
неофициальных сиквелов, мне хотелось бы отметить, что эти фильмы говорят о кризисе Гонконга более остро, чем «Мистер Вампир», переходя от призрачности к материальной телесности вампиров по мере приближения передачи власти ${ }^{1}$.

Как отметил Рей Чоу, кинематографические тексты не могут быть сведены к симптоматическому выражению момента и места их производства (Chow, 1994). Тем не менее, я хочу установить связь между кён-си фильмами с историческим и культурным контекстом, в котором они производились, распространялись, выставлялись и потреблялись, чтобы показать, что потенциальное политическое содержание фильма может способствовать постановке вопросов, которые ученые поднимают в отношении гонконгского кино в целом и которые были сформулированы при анализе художественных фильмов, таких как работы Вонга Карвая и Стэнли Квана, или более дорогих коммерческих фильмов, таких как работы Джона Ву и Цуй Харка.

Появление фильмов о кён-си совпадает с ускоренным осознанием неопределенности и определенности будущего Гонконга. Будучи колонией с тех пор, как в 1898 году Великобритания получила в 99-летнюю аренду Новые территории Сянгана у маньчжуров (династия Цин), Гонконг в своем прошлом, настоящем и будущем неизменно связан с событиями в других частях «Большого Китая», включая свержение династии Цин и создание Китайской Республики (КР) в 1912 году, изгнание правительства Гоминьдана (КМТ) на Тайвань и провозглашение КНР в 1949 году, Великую культурную революцию пролетариата с 1966 года до смерти Мао Цзэдуна в 1976 году и расправу над студентами на площади Тяньаньмэнь, выступавшими за демократические реформы в 1989 г..

В конце 1970-х и начале 1980-х гг. гонконгская идентичность оказалась в кризисной ситуации, когда премьер-министр КНР Дэн Сяопин провозгласил идею «одна страна, две системы» в отношении Гонконга, Макао и, как утверждают некоторые, Тайваня. Визит премьер-министра Великобритании Маргарет Тэтчер в КНР в 1982 году показал первые ощутимые шаги к «воссоединению Гонконга с Китаем», ставшего официальным с подписанием китайско-британской совместной декларации о будущем Гонконга в 1984 гг.. Гонконгу будет позволено сохранить капиталистическую систему еще на полвека (1997-2046), поддерживая одну из форм модернизации, которая часто находилась в оппозиции к монопольным структурам власти в коммунистической модели КНР. Тем не менее, Гонконг не реализовал постколониальный суверенитет способами, сравнимыми с деколонизацией в других странах; фактически, его статус САР указывает на проблемы китайской модер-

1 Согласно Райану Лоу, Гонконгской базе данных фильмов (HKMDb), www.hkmdb.com, (без даты; от 14 декабря 2002 года и 14 января 2007 года), Мистер Вампир заработал 20,1 млн. гонконгских долларов, в то время как «Вампир против вампира» заработал только 11,2 млн. гонконгских долларов, «Укус любви» - 10,8 млн. гонконгских долларов, а «Доктор Вампир» - 2,9 млн. Для сравнения, «Мистер Вампир 2» заработал 13,1 млн гонконгских долларов, а «Новый мистер Вампир» - 17,1 млн гонконгских долларов. 
ности, такие как специальные экономические зоны (СЭЗ) - районы, где неолиберальные экономические законы способствовали иностранным инвестициям, с начала 1980-х гг.. Уход британских колониальной администрации не привел к созданию современного, суверенного, территориального национального государства Гонконг по примеру национальных государств, возникших на основе Вестфальской системы в 1648 гг., всего через несколько лет, кстати, после маньчжурского завоевания Китая.

Абстрактные страхи и тревоги после 1984 г. обрели физическую форму в 1989 г., когда на площади Тяньаньмэнь произошло массовое убийство студентов. По всему миру в прямом эфире по спутниковой связи транслировались изображения их изуродованных тел, воплощая в картинках «кризисные эмоции» Гонконга на примере «кризисных тел» жителей материка. Страхи исчезнуть или раствориться в КНР, а также тревоги по поводу заселения и перерождения в виде (не)постколонии, таким образом, являются частью социального контекста, в котором возникли фильмы о кён-си. Характеризуя всю сложность этого «кризиса», профессор Акбар Аббас охарактеризовал массовые демонстрации сотен тысяч представителей среднего класса в Гонконге, произошедшие после резни, как «редкий момент, когда экономические мотивы могли так легко выдать себя за политический идеализм» (Abbas, 1997, p. 5).

Поскольку гонконгское кино обращено к зрителям Гонконга, Восточной и Юго-Восточной Азии, Африки, Южной Азии, Европы и Америки, смыслы, вкладываемые в его продукцию, множественны; поэтому их нельзя свести к монолитной, коллективной реакции на отношение Гонконга к Великобритании и КНР. Разные аудитории смотрят фильмы о кён-си по разным причинам. В Европе и Северной Америке, например, фильмы привлекают китайскую и другие диаспоры Восточной и Юго-Восточной Азии, а также местных поклонников боевых искусств и фильмов ужасов. Стефан Хаммонд и Майк Уилкин, в частности, пишут: «Наши братья-кровопийцы с Востока не расхаживают в плащах, демонстрируя очарование Старого Света или соблазнительно покусывая шеи - хотя они и живут в гробах и имеют здоровые резцы» (Hammond \& Wilkins, 1996, p. 25) ${ }^{1}$. Чун и Чу отмечают: «Привлекательность кино для фанбоев и им подобных заключается в его тройном притяжении - эротическом, экзотическом и кинетическом», что порождает огромное количество «развлекательных гидов, наряду с многочисленными фан-клубами, веб-сайтами и журналами для киноманов», которые «стимулируют и поддерживают потреб-

1 Далее, Хаммонд и Уилкин пишут (р. 89-90):

«Источником вдохновения послужили многовековые китайские легенды, в которых легионы прыгающих вампиров являются обычной частью повседневной жизни, и с их существованием мирятся, как мирятся с плохой погодой. Вместо коварных восточноевропейских парней в формальной одежде, очаровывающих дам и кусающих их бледные, невинные шеи, мы видим вампиров в виде облаченных в минские одежды трупов. Навечно закоченевшие, кён-си («прыгающие призраки») страшны, но в них есть и милая, игривая сторона. А дети-вампиры всегда милы. При этом вампиры часто являются помощниками более могущественных демонов и ведьм. И такие монстры совсем немилые». 
ление и глобальную циркуляцию ориенталистских и стереотипных образов Гонконга через жанровое кино»(Cheung \& Chu, 2004, p. xiii).

Хаммонд и Уилкин, таким образом, стремятся показать культурные различия между «вампирами» Гонконга и «Старого Света», осознавая, что такие конструкции являются кинематографическими фантазиями. Более того, их обобщение, здесь, в описании «Мистера Вампира», умалчивает о вариациях внутри фильмов о кён-си. Персонажи в фильмах «Вампир против вампира», «Укус любви» и «Доктор Вампир» вообще-то «расхаживают в плащах», как и граф Дракула. Плащ вампира, конечно, служит важным, культурно специфическим реквизитом в европейских/голливудских фильмах о вампирах, а также в фильмах, снятых в Мексике, Японии, Пакистане и других местах, где культурно специфические традиции европейских/голливудских фильмов были транскультурно адаптированы. Как и клыки, плащ физически маркирует вампира как Чужого, призрачное и потенциально угрожающее присутствие из другого времени и места. Возможно, отсталый или ретроградный, возможно, «досовременный» или феодальный, иммигрант, изгнанник или беженец, угрожающий поглотить принимающую культуру.

В эпоху глобального капитала кинематограф часто должен выбирать между общими культурными мотивами и культурной спецификой, «правильно их сочетать», по выражению, использованному в другом контексте создателями болливудской масалы, чтобы привлечь как искушенную, так и наивную аудиторию. Коммерческие фильмы вроде фильмов о кён-си были упущены из виду академической науки на фоне пристального внимания к фильмам Новой волны в Гонконге и Тайване, а также к работам кинематографистов пятого и шестого поколений в КНР. Как утверждает Роберт Стэм, гибридность выражает себя не только через культурные объекты, но и через сам процесс проявления, способ конституирования себя как текста (Stam, 2003, p. 40). Хочется заметить, что присутствие европейского/голливудского вампира в гонконгском кино трансформирует страх перед передачей власти КНР в амбивалентные антиколониальные, антииностранные и антихристианские нарративы - амбивалентные, потому что они кажутся ностальгией по эпохе, когда различные конфигурации транснационального (или, возможно, даже донационального) сознания были еще возможны.

Вампиризм и вампиры - это тропы и образы, которые были взяты на вооружение романистами, драматургами, кинематографистами и другими авторами за последние несколько веков для исследования и повествования о современных субъективностях. Кроме того, вампиризм и вампиры - это еще и тропы, и образы, взятые на вооружение теоретиками для критики в политической экономии. Например, в первом томе «Капитала» Карл Маркс пишет, что «капитал - это мертвая производительная сила, которая, подобно вампиру, живет, высасывая жизнь, и живет тем больше, чем больше ее высасывает» (Marx, 1977, p. 342). В повседневной журналистской практике вампиры исполь- 
зуются при обсуждении транснациональных медиакорпораций. «Это было неизбежно: в быстро сужающемся мире глобальных развлечений Голливуду суждено было открыть Гонконг», - провозглашает американский еженедельный журнал новостей; «Может ли вампир устоять перед свежей кровью?» (Ansen, 1996, p. 66). В то время как Маркс использует вампиризм как метафору для описания наиболее эксплуататорских и недемократических свойств капитализма, Майкл Хардт и Антонио Негри прибегают к вампиру как метафоре для обозначения средств противостояния «Империи», их противоречивой концепции мирового порядка глобального капитализма после холодной войны (Hardt \& Negri, 2000) $)^{1}$ «Вампир - это единственная фигура, которая выражает чудовищный, чрезвычайный и непокорный характер плоти множества», пишут они (Hardt \& Negri, 2004, р. 193) 2 . Для них «Множество» открывает возможности внутри детерриторизированных и фрагментированных властных структур глобальной войны Империи. Именно в этих противоречиях внутреннего смысла вампиров и вампиризма - эксплуатации и сопротивления, капитала и плоти - лежит суть моего анализа кён-си в гонконгских фильмах. Вампиризм можно понимать как троп, обозначающий мощные способы производства в рамках глобальной экономики, особенно в эпоху ускоренной глобализации, когда идентичность часто становится товаром.

\section{Транскультурный подход к транскультурному производству}

Аббас, развивая понятие déjà disparu, отмечал: «Чувство, что все, что является новым и уникальным в какой-то ситуации, уже навсегда исчезло», так что остается «горстка клише или набор воспоминаний о том, чего никогда не было» (Abbas, 1997, p. 25). Концепция Аббаса о déjà disparu перекликается с прочтением Стивеном Тео центральной роли даосских священников в повествованиях фильмов о призраках и кён-си как маркера «ценностей и идеологий, которые современный, даже постмодернистский гонконгский кинематограф пытается осмыслить, отказываясь от упрямой живучести досовременных способов мышления после исторического момента, когда они уже должны быть мертвы, как кадавры» (Тео, 1997, р. 224). Внимание ученых к гонконгским комедийным хоррорам было сосредоточено на историях о привидениях, отчасти из-за их сложной взаимосвязи с китайскими литературными и оперными традициями, а также из-за производства фильмов о привидениях режиссерами новой волны, такими как Энн Хуэй и Стэнли Кван. При этом фильмы о кён-си обделены исследовательским вниманием и требуют иной аналитической перспективы. И хотя рассмотрение фильмов через «нелокальную» призму неизменно чревато ошибками, их игнорирование,

1 Критика этой работы представлена в книге «Debating Empire» (Aronowitz et al., 2003)

2 Автор благодарит Шитал Маджития за ссылку на эту работу. Критику «Multitude» cм. B: (Rofel, 2001) 
особенно с учетом их популярности не только в Гонконге, но и во всей ЮгоВосточной Азии, потенциально еще страшнее 1 .

Итак, я надеюсь, что мой анализ этих фильмов не будет похож на ошибочное представление о европейском/североамериканском доминировании над гонконгскими фильмами (то, что Тео назвал после подвигов Т. Э. Лоуренса в Аравии «Лоуренс-критикой»), а будет работать в пространстве транскультурного сравнительного анализа (Тео, 2002, pp. 183-184)1. Подходя к теме инородного Дракулоподобного вампира - а в случае с гонконгским кино - вдвойне чужеродного, поскольку Дракула определяется как чужой по отношению к знакомым английским, голландским и американским персонажам романа Стокера - хотелось бы сделать акцент на апроприащии и миликрии, а не на имитащии.

Хотя критики серьезно отнеслись к фильмам о кён-си, они также отвергли более поздние фильмы причинам, заслуживающим, по моему мнению, внимания. При анализе фильма «Мистер Вампир», критики могут добавлять оценочные комментарии, например, «Отходя от традиционных китайских верований о трупах, призраках и Дао, последующие фильмы все больше черпали вдохновение в стандартных голливудских ужастиках и отказывались от творческого слияния, смешения и мистификации Восточной и Западной культур» (Hoover \& Stokes, 2002, p. 75). Однако, культура и так уже «смешана», как в Гонконге, так и в Голливуде, который к 1989 г. все чаще стал нанимать талантливых гонконгцев. Кроме того, такое смешение имело долгую историю, послужившую как гонконгскому, так и европейскому/голливудскому кинематографу. «Стремление гонконгской киноиндустрии выйти на международный рынок, найти потребителя за пределами традиционного китаеязычного рынка, приводит к возможности построения глобальной идентичности», - объясняет Тео. «Как показывает пример фильма «Легенда о семи золотых вампирах» (Великобритания-Гонконг 1974), бывают случаи, когда эта попытка найти нишу на глобальном рынке может дать не совсем удачные результаты, хотя и интересные для просмотра, из-за очевидных попыток включить популярные элементы как восточной, так и западной культур» (Тео, 2000). Транскультурность, таким образом, занимает центральное место в гонконгском кинематографе.

Во введении к каталогу Гонконгского международного кинофестиваля 1989 года, посвященному «призракам», Ли Чук-то утверждает, что «лишь в 1974 г., после всемирного успеха голливудского фильма «Экзорцист» (США, 1973; реж. Уильям Фридкин), в гонконгском кино появился устойчивый, узнаваемый жанр ужасов» (Li Cheuk-to, 1989, p. 9). Ын Хо уверен, что «Мистер Вампир» «совершил прорыв, показав, что гонконгское кино наконец-то усвоило все, что могло, из западных фильмов о вампирах и перешло к использованию истинно китайского фольклора», однако он также отмечает, что «гонконгская «вампир-

1 Обсуждение сложностей транскультурного анализа см. в статье (Thomas, 1985) 
ская культура» в лучшем случае является вторичной» (Ng Ho, 1989, p. 31). В отличие от западных вампиров, которые «символизируют стремление человечества к бессмертию, к вечности», гонконгские вампиры - это «лишь оболочки из шевелящейся, гниющей плоти». Как и все транскультурные фигуры, кён-си расшатывает опоры культурной чистоты (китайской, британской, английской, ханьской), выводя на первый план живучесть того, что часто называют «заразностью».

Основной вопрос при изучении фильмов кён-си - существуют ли в Китае «вампирские истории», которые можно соотнести с европейскими. «За исключением легенды о «погонщиках трупов из Сянси» (Сянси - старый административный район в провинции Хунань), почти наверняка никто не слышал о вампирских историях, - пишет Ын Хо. Когда-то я сомневался, что вампиры вообще существуют в Китае» (Ng Ho, 1989, р. 29) ${ }^{1}$. Легенда о «погонщиках трупов из Сянси», источник которой до сих пор остается неустановленным, важна:

«Эта странная практика перевозки трупов, по-видимому, берет свое начало в среде (основное население Китая), переселившихся в отдаленные и гористые районы в верховьях реки Юань в Хунане, где они оказались в меньшинстве. После смерти, по мнению ханьцев, покойник должен был лежать в родной земле. Из-за труднодоступной горной местности единственным способом доставки трупов на родину был так называемый метод «погонки трупов», который практиковали - и до сих пор практикуют - даосские священники (fat si)» (Ng Ho, 1989, p. 30).

Маловероятно, что значение «родной земли» в этой легенде, а также в романе Стокера «Дракула» и его кинематографических адаптациях, в которых «родная земля» служит в качестве метафоры изоморфной связи Дракулы с «нацией» (Трансильванией), является более чем совпадением. Тем не менее, легенда дает представление о том, как кён-си и вампиры соединились в фильмах о кён-си. Фигура кён-си идеально подходит для анализа гонконгской идентичности, которая часто мыслится как кризис между отчаянием и надеждой, исчезновением и перерождением, угрозой и избавлением, смертью и обновлением, а также метафорой практик приспособления к местным и глобальным рынкам².

Хотя термин «китайский прыгающий вампир» указывает на европоцентризм, ориентализм, колониализм и другие расистские легитимации для создания эссенциализированной китайскости в англоязычном воображении, этот термин также намекает на транскультурность как на продуктивное поле сопротивления, диалога и креативности. Предположительно, формулировка

1 Он продолжает: «До сих пор никто не смог установить аутентичность легенды. Покойный кинопродюсер Чжан Шанькунь снял фильм под названием «Погонщики трупов из Сяньси» (Гонконг, 1957). В нем рассказывалось о группах контрабандистов, которые использовали трупы в качестве тайников для контрабанды запрещенных веществ» (р. 29).

2 Например, на рекламных плакатах и видео-боксах к фильмам о кён-си часто изображены два маленьких клыка с капающей кровью. Хотя эти клыки можно трактовать в контексте призраков или демонов, которые появляются во многих фильмах, клыки также наводят на мысль о западных вампирах. 
«nрыгающие валпиры» была придумана гонконгскими рекламщиками в качестве маркетинговой практики, демонстрирующей стратегическую изюминку, необходимую для получения доступа к региональным и глобальным рынкам ${ }^{1}$. Обвиняемое часто в «региональном империализме», гонконгское кино является гегемонным, и подобно Болливуду и Голливуду, нередко нивелирует маркеры национальной идентичности, чтобы соответствовать ожиданиям различной международной аудитории. В то же время, формулировка «гонконгская национальная идентичность» является ошибочной в том смысле, что национальная идентичность обычно понимается как нечто связанное с современным национальным государством. Если Гонконг усвоил все, что мог, из европейских/голливудских фильмов о вампирах, как предполагает Ын Хо, то из этого может следовать, что гонконгские фильмы о кён-си, снятые после 1989 г., изрыгнули (если продолжить гастрометафоры, хотя другие метафоры могут быть более уместны) то, что было усвоено в них, и вывели это на экран вместе с европейскими/голливудскими вампирами; то есть гонконгские комедийные ужастики смогли конкурировать на равных с британскими и голливудскими. Если модерность - это кризис, то кризис может быть продуктивным.

\section{Модерность как кризис - Гонконгский кинематограф}

Под китайской модерностью часто понимают начало трансформации цинского Китая в современное национальное государство. Иными словами, провозглашение суверенитета Китая потребовало подчинения мировому порядку, продиктованному Европой (Berry \& Farquhar, 2006, p. 23). Гонконг в этом контексте - совершенно особый случай. Крис Берри и Мэри Фаркухар характеризуют «постколониальную постмодерность Гонконга (когда-то колонии, теперь САР, но никогда не национального государства) как временное состояние, несоизмеримое с прогрессом современности и особенно сопротивляющееся ему»(Berry \& Farquhar, 2006, p. 38). Дай Цзиньхуа много писала об изменениях, произошедших в китайском кино в связи с глобализацией, и пришла к выводу, что режиссеры Пятого поколения в КНР застряли между доиндустриальным и постмодернистским в «типично модернистской попытке выразить невыразимое»(Dai, 2002, p. 49). В отношении Гонконга она отмечает особое беспокойство в связи с ослаблением британской колониальной демократии и быстро меняющимся и постоянным процессом централизации, исходящим от правительством КНР, что проявилось в том, что «национальная граница «Холодной войны» между Гонконгом и материком обозначила (в обратном направлении) глобальное разделение между Севером и Югом, то есть.. между глобальным богатством и бедностью» (Dai, 2005, p. 82). Хотя гонконгские (и тайваньские) фильмы о боевых искусствах и выражают тревогу по отношению к 1997 году, она считает, что они сыграли центральную роль

1 Стивен Тео писал о гонконгских рекламщиках в своей книге (Тео, 1997, p. 219) 
в способности КНР «позиционировать себя в процессе быстрой глобализации» (Dai, 2005, p. 92)․ Современный Шанхай и другие города демонстрируют трущобы и потогонные цеха, расположенные в тени постмодернистских офисных башен и роскошных резиденций, в точности как Гонконг и другие «мегаполисы», такие как Токио, Лондон и Нью-Йорк, заметнее, чем это было до краха советского коммунизма ${ }^{2}$.

Несмотря на свое глобальное значение, гонконгское кино остается субкультурным («странным, чудаковатым, заумным» или «популярным»), региональным («азиатским») или транснациональным («китайским») - кино, которое обычно определяют как «национальное» или как часть «мирового кино», а не гегемонное и глобальное вроде Голливуда (Morris, 2005, p. 3) ${ }^{3}$. Однако, как отмечает Энн Сикко, «явно пришло время перерисовать карту мирового кинематографа и расположить Азию в центре» (Ciecko, 2005, p. 6) ${ }^{4}$. Меган Моррис утверждает, что «переведенные на множество языков гонконгские фильмы тиражируются не только как «гонконгское кино» или «китайское кино», но и как жизненно важная в определенных местах часть местной кинокультуры» (Morris, 2005, p. 4). Хотя Гонконг производит меньше фильмов, чем индустрия на тамильском или хинди в Индии, его стратегии производства коммерчески жизнеспособных и технически инновационных фильмов для местной и региональной аудитории позволяют говорить об историческом предшественнике «корейского чуда» начала 2000-х годов, хотя и без санкционированной государством (как Южной Корее) политики глобализации (Segyehwa). В отличие от большинства «национальных кинематографов», которые определяют себя в соответствии с современным государственным национализмом в оппозиции к Голливуду, гонконгское кино является преимущественно мейнстримовым, а Голливуд служит «скорее моделью и партнером, чем «Другим», которому нужно сопротивляться, отталкивать его или деконструировать»( Cheung \& Chu, 2004, p. xxiv). В середине и конце 1980-х годов гонконгское кино считалось «маргинальной империей, тесно связанной с Голливудом»; то есть, оно было скорее комплиментарно, чем оппозиционно Голливуду (Chu, 2004, p. 5). Помимо Голливуда, гонконгский кинематограф опирается на японские традиции фильмов тянбара («бой на мечах»), аниле и манга (K. S. Yau, 2005). Когда подчеркивается его отличие, это скорее

1 B «Order/Anti-order» Цзиньхуа (р. 93) объясняет:

«В начале 1990-х годов гонконгские фильмы, популярные в материковых кинотеатрах, служили воображаемым пространством и источником культурной разрядки после событий 4 июня 1989 года, вскоре они стали эталоном для самоидентификации и самовыражения материковой молодежи, растущей во фрагментированном и неэффективном идеологическом пространстве между воображаемым, глобализацией и реальностью».

2 По поводу проблем третьего мира в городах первого мира см. (Sassen, 1991)

3 Примеры исследований гонконгского кино как регионального, национального или транснационального см. в (Bordwell, 2000; Fu \& Desser, 2000; Lu, 1997; Stokes \& Hoover, 2000; С.-M. Е. Yau, 2001; Y. Zhang, 2002) и другие труды, упомянутые в этой работе.

4 Она цитирует режиссера Шекхара Капура, который утверждает, что в нынешнем тысячелетии произойдет переход к глобальной медиакультуре, центром которой станет Азия. 
«отличие от другого китайского кино», как показывают Чун и Чу. Гонконгские фильмы представляют Гонконг как физически ханьский, и в то же время, перформативно, как космополитичный, потребительский и капиталистический, в противовес революционному реализму и романтизму «революционных кинематографистов» третьего поколения в КНР.

Квай-Чун Ло, говоря о репрезентации Китая в гонконгском кино, пишет, что «гонконгское кинопроизводство никогда не утверждается как националистическое образование, противостоящее универсалистскому стремлению модернизации», потому что «местное», как основной источник национальной идентичности, «возникает между национальным дискурсом и глобальной структуризацией и остается колеблющимся и неустойчивым» (Lo, 2001, p. 263). Тео отмечает, что гонконгское кино с 1970-х годов проецирует «абстрактный национализм», основанный на tianxia, моральных и культурных традициях родины, а не на конкретной политической верности (Bordwell, 2000, p. 40). Сиу-Люн Ли утверждает, что кунг-фу-боевики показывают отношение Гонконга к собственной китайскости как амбивалентное (S. L. Li, 2001). Враги Брюса Ли, например, часто не принадлежали конкретной культуре или эпохе, особенно в экспортных копиях для Японии; тем не менее, Ли побеждал своих врагов. Фильмы, снятые в период с 1970-х по 1984 гг., демонстрируют оптимизм, который Аббас описывает следующим образом: «Колониализм казался почти несущественным, не более чем формальным административным присутствием, которое не вмешивалось в реальную жизнь колонии» (Abbas, 1997, p. 30). Действительно, до 1949 года Гонконг почти не предлагал природных или человеческих ресурсов для эксплуатации; скорее, Гонконг служил «пространством для содействия», которое было одновременно автономным и зависимым, местом, где «“премодерн" и "постмодерн" соединились, - объясняет Аббас, - без необходимости признавать друг друга» (р. 72-75). Поскольку Гонконг исторически является перевалочным пунктом для изгнанников цинского двора и беженцев, японцев, членов Гоминьдан и Коммунистической партии Китая (КПК), Аббас (р. 25) утверждает, что до 1984 г. гонконгский кинематограф обращался к КНР и КР(Тайвань) за «легитимной историей». К 1990-м гг. большинство критиков согласились с тем, что гонконгскому кинематографу уже невозможно было полагаться на «панкитайские фантазии о подлинной 'китайскости'» или игнорировать глобализацию, поэтому кинематограф перешел к «новому локализму» и скрытой политике (Marchetti, 1998, p. 68).

Аббас утверждает, что гонконгское кино является коммерческим в силу необходимости (отсутствие государственного финансирования со стороны колонизаторов), но, с момента визита Маргарет Тэтчер в КНР в 1982 г. для начала обсуждения передачи власти, оно является коммерческим, будучи обращенным к «обществу, находящемуся в процессе изменения - обществу,

1 Это слово характеризует Китаецентричный взгляд на мир, где поднебесную окружают «варвары». 
внезапно обеспокоенному своей культурной идентичностью, поскольку так много социальных и политических свобод зависят от этого вопроса» (Abbas, 1997, p. 23). Гонконг становится объектом гонконгского кино, утверждает он, поскольку культурная идентичность понимается как необходимое условие для утверждения политической автономии. Берри и Фаркухар в своем недавнем анализе коснулись «кинематографических значений национального» в китайском кино, отметив, что «наиболее важным вопросом» является «производство коллективной идентичности и, на ее основе, агентности», которая не является «единой и последовательной», а «многократно конструируется и оспаривается» (Berry \& Farquhar, 2006, p. 9). Коммерческие реалии Гонконга отличают его кино от «продиктованных реалистических модальностей с мелодраматическими хэппи-эндами для различных национальных целей» КНР (т.е. классовой справедливости) и КР (мелкого капитализма), объясняют Берри и Фаркухар (р.12, 77), так что реализм является эстетическим выбором, служащим построению Китаем себя как современного национального государства как в КНР, так и в КР.

\section{Кризисные эмоции: заражение и сопроизводство}

Конкретные исторические условия фильмов о кён-си подтверждают, что кён-си появляется в периоды политического, социального и духовного дисбаланса. Действительно, появление цикла о кён-си совпадает с периодом дисбаланса в Гонконге после обсуждения будущего колонии в 1982 г.. B промышленном плане «Shaw Brothers» столкнулись с новой конкуренцией после достижения фактической монополии на рынке коммерческих фильмов Гонконга на путунхуа, когда Cathay Organization прекратила в 1970 г. производство фильмов. Борьба без оружия (кунг-фу) несет в себе символику китайскости, которой нет в фильмах уся (т.е. о боевых искусствах), поскольку они заимствуют традиции из японских фильмов тянбара и голливудских фильмов. В народном воображении кунг-фу связано с китайской оперой, даосизмом, антииностранным патриотизмом времен Восстания Ихэтуаней, и популистскими развлекательными фильмами на кантонском языке (Yang, 2003, p. 52). Решение Брюса Ли подписать контракт с Golden Harvest, a не c Shaw Brothers, ознаменовало конец эпохи. Дай Цзиньхуа утверждает, что «появление» особого типа фильмов в 1980-х и 1990-х гг. - «классических костюмированных анекдотических историй» (guzhuang baishi pain) - на самом деле является «повторяющимся кинематографическим явлением в истории китайского кино, проявляющимся во времена социальных потрясений, тревоги и неопределенности» (Dai, 2005, p. 82). Разница, как отмечает Цзиньхуа (р. 85-86), между гонконгскими фильмами о боевых искусствах, повествующих о конце династии Мин и династии Цин, когда каждая столкнулась с крахом, предполагает различные концепции современного китайского национального государства: в первом случае, ханьский Китай подвергается нападению 
неханьских сил; во втором - меньшинство (маньчжуры) управляет большинством (т.е. ханьцами).

Критики утверждают, что вампиры и в голливудском кино появляются в моменты кризиса ${ }^{1}$. Столкнувшись с олигополическим контролем голливудской «большой пятерки» студий, и опасаясь утратить контроль над Universal Studios (США), Карл Леммле-младший сосредоточился на недорогих фильмах с классическими монстрами - Дракулой, Франкенштейном, Мумией, Человеком-невидимкой, Фу Манчу (Gomery, 2005, p. 158). Цикл хорроров студии Hammer (Великобритания) появился аналогичным образом (Hutchings, 2001). Первый фильм о вампирах, «Дракула» / «Ужас Дракулы» (Великобритания, 1958; реж. Теренс Фишер), на самом деле был частично профинансирован Universal. В середине 1970-х гг. этот цикл Hammer исчерпал себя, настало время «увлечения кунг-фу», особенно на доходном североамериканском рынке. В сотрудничестве с Shaw Brothers, чье доминирующее положение в фильмах о боевых искусствах также начало ослабевать в 1970-х гг., они выпустили фильм «Легенда о семи золотых вампирах» (Великобритания-Гонконг 1974; реж. Рой Уорд Бейкер), который рекламировали как «первый ужастик с кунг-фу». Международные совместные проекты британских и иностранных кинокомпаний были редкостью из-за позиции британских профсоюзов.

В фильме «Легенда о семи золотых вампирах», снятом полностью в Гонконге, Питер Кушинг играет роль профессора Ван Хельсинга, который едет читать лекции в университет в Чунцин, первый китайский внутренний порт, открытый для иностранцев в 1891 году (за тринадцать лет до начала действия фильма) $)^{2}$. Ван Хельсинг узнает о «семи золотых вампирах» в проклятой деревне в провинции Сычуань. Столетием ранее граф Дракула вселился в тело Ка (Чань Шень), настоятеля храма семи золотых вампиров, который отправился в Трансильванию, чтобы заручиться поддержкой Дракулы. Пока преподаватели Чунцинского университета смеются над суеверностью Ван Хельсинга, Си (Хси) Син (Дэвид Цзян) рассказывает Ван Хельсингу, что его дед уничтожил одного из семи золотых вампиров. С помощью и под защитой Си Сина, его братьев и Май Квей (Ши Сы) Ван Хельсинг и его сын Лейланд (Робин Стюарт) побеждают оставшихся шесть золотых вампиров и Дракулу. К арсеналу традиционного оружия против вампиров добавляются мечи и боевые искусства. Как и Дракула, китайские золотые вампиры превращаются в летучих мышей - это западная идея, которая обычно считается немыслимой для китайцев, поскольку вопросы загробной жизни требуют, чтобы физическая,

1 «Дракула явно притягивает нации, переживающие кризис», - утверждает Ким Ньюман в рецензии на фильм. Он приводит список крупных экономических и социальных потрясений, которые совпали с основными киноверсиями романа «Дракула»: «Германия, 1922 г.. Америка, 1930. Великобритания, 1958. Америка, 1979. Америка, 1992», ознаменовав 1992 г. «рецессией и смещением Буша»(Newman, 1993, p. 12).

2 Использование костюмов в этом фильме позволяет адаптировать местные виды для изображения центральной Европы, что наиболее заметно в кадре с замком Дракулы в Гонконге. Чунцинский университет был основан только в 1929 году, через четверть века после визита профессора Ван Хельсинга. 
человеческая форма оставалась нетронутой для реинкарнации (Тео, 1997, p. 219) ${ }^{1}$. Типично для британского кинематографа того времени, выживают только белые мужчины и китаянка ${ }^{2}$. Тео интерпретирует этот совместный фильм как попытку обеих студий перепозиционировать себя на международном кинорынке. «Киностудия "Shaw Brothers" хотела воспользоваться популярностью кунг-фу, которая возникла благодаря Брюсу Ли, а Hammer Pictures увидела возможность расширить свое влияние и долю рынка в Азии», - объясняет он. Рассматривая фильм как текст, он пишет: «В начальных сценах мы видим, как Дракула принимает облик китайского настоятеля храма. «Я воспользуюсь твоим образом, твоей мантией», - говорит Дракула». В центре дебатов о глобализации стоит вопрос о гегемонии глобального Севера, культурного империализма США, и эту сцену можно рассматривать как индикатор того, как глобализация отталкивается от идеи доминирования и подавления».

Глобализация подразумевает взаимозависимость, пусть часто неоднородную и неравноправную. Совместное производство Hammer c Shaw Brothers, находящейся в британской колонии Гонконг, предполагает движение к транскультурному по имперскому вектору. В то же время гонконгские кинокомпании, такие как «Golden Harvest», почувствовали исчерпанность цикла о кён-си от «Во Но Film» и обратились к транскультурности, но уже постколониальной. Так были сняты новые фильмы с европейскими / голливудскими вампирами.

\section{Кризисные тела: кён-си и вампиры}

Одним из известных примеров китайских повествований о привидениях является произведение «Рассказы Ляо Чжая о необычайном» Пу Сунлина (1640-1715), автора историй о сверхъестественном, известного как Мастер Ляо Чжай. Написанные в мелодраматическом стиле, известном как чуаньци ${ }^{3}$, рассказы подчеркивают разделение разума и тела: инь - мир призраков, ян мир людей, а человеческое тело - место сражений. Тэо интерпретирует стиль письма Пу как сопротивление иностранной маньчжурской оккупации ${ }^{4}$

1 Тео утверждает (р. 223), что гонконгские фильмы «ужасов» обязаны Голливуду и Хаммеру, а также местным литературным и кинематографическим традициям. Тема реинкарнации в истории о призраках, пишет Тео, позволяет создать «аллегорический рассказ о предательстве и судьбе, трансформирующий персонажей в путешествии по психологическому царству, где прошлое определяет настоящее». Обезглавливание является высшей формой смертной казни, поскольку обезглавленный человек не имеет права на реинкарнацию и обречен на вечное наказание в качестве потерянной души, блуждающей в аду.

2 «The Satanic Rites of Dracula/Count Dracula and His Vampire Bride» (Великобритания 1973; реж. Алан Гибсон) также обращает внимание на глобальный капитализм, в частности на то, как капитал «высасывается» по колониальным и постколониальным каналам. Главной ученицей Дракулы в этом фильме является китаянка Чинь Ян (Барбара Ю Лин), что намекает на выбор актеров по расовому признаку и служит комментарием к беспокойству Великобритании по поводу оздоровления экономики ее китайской колонии.

3 Буквально, «рассказы о необычном». (прим. Пер.)

4 Тэо пишет: «Фатальность конца династии, ностальгия по периоду Мин, антипатия к существующему порядку (отраженная в тяжелой судьбе ученых) - вот основные темы Ляо Чжая. Пу рассказывал истории о 
Призраки и демоны ищут тела для перевоплощения, а мертвые принимают форму абстрактных духов, обычно проявляющихся в этих рассказах в виде лисиц, или человеческих фигур, забирающих жизненную силу через сексуальные контакты. Духи обычно были прекрасными женщинами, умершими в результате несправедливости, часто из-за неудачной любви. Для таких духов покой приходит через возрождение и реинкарнацию. Истории о призраках восходят к золотому веку шанхайского кино. Фильм Стэнли Квана «Yin ji kau/ Rouge/Румяна» (Гонконг, 1987) стал популярным и получил признание критиков, что оживило жанр, привнеся в него качественное производство и участие звезд кино. В некоторых фильмах призрака разоблачают как мистификацию. История здесь раскрывается не прямо, а образно, как «чувство потери» (Chan, 2000, p. 255). Фильмы предлагают сложные способы восстановления, сохранения и передачи из поколения в поколение этой воображаемой истории. Местная идентичность, пишут Берри и Фаркухар, формируется с помощью прошлого в фильмах-наследии (и пост) в ответ на современные процессы глобализации (Berry \& Farquhar, 2006, p. 77).

Рассматривая призрака как образ нестабильного времени, где прошлое, настоящее и будущее обрушиваются друг на друга, Берри и Фаркухар приходят к выводу, что совместное присутствие прошлого и будущего «дестабилизирует саму идею четко определенного настоящего, являющуюся фундаментом современного линейного времени» (р. 39). Неудивительно, что Гоминьдан запрещал истории о привидениях и боевых искусствах в своей компании 1935 г. по «борьбе с суевериями и моральным упадком» (Abbas, 1997, p. 40). Очевидно, что линейное движение модерности к осознанию Китаем себя как современного национального государства было нарушено этими символами прошлого. Они отмечают, что «киноопера - это форма культурного национализма, которая может быть преобразована государственными директивами в политический национализм», однако, пока не появилась ее версия, прославляющая идеалы социальной революции, КНР воспринимала ее как нечто проблематичное из-за «феодального содержания и регионального разнообразия, обратной стороны грандиозного повествования о современной нации» (р. 48). В то время, как Гоминьдан запретил призраков и боевые искусства, отмечают Берри и Фаркухар, КПК присвоила и превратила их в основу национального государства (р. 59).

Вампиры, как призраки и трупы, являются досовременными пережитками феодального и династического порядка. По мнению Франко Моретти, персонаж Брэма Стокера граф Дракула монополистичен, так как «буржуа XIX века способен представить себе монополию только в виде графа Дракулы,

простых людях, которые отражали все эти темы, принимая кажущуюся объективную позицию как часть 'правильного' подхода» (Тео, 1989).

5 Фильм-наследие (Heritage film) - собирательный термин для фильмов, изображающих прошлое в ностальгических тонах. Изначально применялся относительно британский картин, но в последствии распространился и на фильмы других стран. (прим. переводчика) 
аристократа, фигуры прошлого, реликта далеких земель и темных веков» (Moretti, 1988, р. 91). Монополия представляет собой феодальный порядок, несовместимый с идеалами свободной конкуренции, и, по мнению Моретти, национализм в сочетании с деньгами и религией «координирует индивидуальную энергию и позволяет ей противостоять угрозе». Монополистический капитализм, таким образом, должен быть сдержан современным национальным государством. «Современность побеждает своего врага, - пишет Стив Пайл о романе «Дракула», - благодаря превосходному использованию информации, доступной ее агентам, и превосходному ремеслу - использованию технологий» (Pile, 2003, p. 276). Гонконгские фильмы могут приравнивать чрезмерное накопление богатства к потере человечности, что проявляется в обличье кён-си. Духи - это лиминальные фигуры, оказавшиеся между временем и пространством.

«Встречи с приведениями» (Gwai ckui gwai/Spooky Encounters, Гонконг, 1980; реж. Саммо Хун Кам-бо) многие считают первым фильмом о потустороннем, изображающим кён-си, а также одним из первых гонконгских комедийных хорроров ${ }^{1}$. Как и в фильме «Мистер Вампир», в роли кён-си снялись известные мастера боевых искусств, прошедшие обучение в Китайской драматической академии (как и Джеки Чан и Саммо Хун). В фильме представлена традиция поединка двух сифу (мастеров), Чин Хоя (Лун Чан) и его брата Цуя (Фат Чун), и показан кён-си (Юэнь Бяо). Несвязанное с этим фильмом продолжение «Встречи с призраками 2» (Gwai aau gwai/ Encounters of the Spooky Kind II, Гонконг, 1980), было снято Рики Лау, а Лам Чин-Ин снялся в роли сифу, уничтожающего вампиров ${ }^{2}$. Имена этих двоих станут почти синонимами фильмов о кён-си.

Новые фильмы жанра уся опирались на японскую тянбару, заново изобретая кино, имитируя необходимое, но сохраняя определенные китайские традиции (Yung, 2005, р. 46). Коу объясняет, что в «Мистере вампире» мотивация кён-си в том, что когда-то он был человеком и может проявлять человеческие качества, такие как тщеславие, уязвимость и другие недостатки. Коу объясняет, что кён-си - это труп человека, умершего плохой смертью. Кён-си отличается от «сыии» (трупа) тем, что сохраняет «дыхание», дожидаясь подходящего момента для оживления. В отличие от европейского/голливудского вампира, который высасывает кровь своей жертвы, кён-си питается дыханием - особенность, которая в последующих фильмах о мистере Вампире менее заметна ${ }^{3}$ Кён-си обычно одеты в традиционную одежду, у них длинные синие

1 Бей Логан утверждает, что «Maau saan goeng shut kuen/The Spiritual Boxer 2» (Hong Kong 1979; peж. Liu Chia Liang), возможно, является первым из сравнительно новых гонконгских фильмов, включившим в свое повествование кён-си (Logan, 1996, р. 103).

2 Термин «несвязанный сиквел» заимствован из книги Фредерика Даннена и Барри Лонга (1997, p. 224). Большинство западных поклонников фильма описывают его в похожих терминах.

3 В книге «Абракадавр: Кросс-культурные влияния в гонконгском кино о вампирах», Ын Хо утверждает: «Что касается мифа о тех людях, чью кровь высасывает вампир, и они сами становятся вампирами. Нет никаких литературных источников, подтверждающих это в китайской традиции. Можно с уверенностью 
ногти и удлиненные клыки, а двигаются они, прыгая с вытянутыми руками. Как правило, они изображаются слепыми и находят своих жертв по дыханию. Они душат людей, протыкая горло своими длинными ногтями. Для борьбы с нечистью сифу использует особые силы и заклинания, называемые «фашу» 1 . Сифу может «усмирить» кён-си, приложив талисман - полоску желтой бумаги, на которой написаны даосские сакральные формулы, - ко лбу кён-си и направляя его движение с помощью колокольчика, или же сифу может уничтожить кён-си с помощью заклинаний, деревянных мечей или собачьей крови (Vié, 1996, p. 175).

В фильмах используется оперный лянсян, «застывшая поза, которая визуально передает "архетипические образы и эмоции"», такие как сопротивление, самоотверженность или ненависть. Она сочетает эмоции (uин) и энергию $(u,)^{2}$. Фильмы усиливают зрелищность боевых искусств с помощью быстрого монтажа и спецэффектов, в частности, тросов, удаленных в процессе постпродакшена, позволяющих персонажам совершать эффектные подвиги в технике, которую фанаты часто называют «трос-фу» (wire-fu). Музыкальные реплики и небольшие пиротехнические средства служат для усиления эффекта магии фашу. Сифу неизменно уничтожает кён-си и исцеляет пострадавших. Наиболее зрелищная сцена драки происходит в конце фильма, за ней часто следует короткий комический момент. Фильмы, как утверждает Ын Хо, в основном посвящены отношениям между сифу и учеником, так что кён-си выступает в качестве объекта, позволяющего выразить этот комический конфликт ( $\mathrm{Ng}$ Ho, 1989 , p. 29) ${ }^{3}$.

Фильмы, снятые такими компаниями, как Bo Ho Film и Golden Harvest, применяют визуальные стратегии костюмированной драмы. Кён-си зачастую одет в традиционную одежду, представая как пережиток прошлого или символ традиции, предок, чья душа должна быть упокоена, чтобы гарантировать процветание и благополучие семьи. Как правило, сифу отличает желтый даосский наряд, во всяком случае, в сценах поединков, так что битвы «добра

сказать, что это в основном западная концепция, использованная и адаптированная в китайскую форму Мистером Вампиром» (р.33). Среди фильмов Рики Лау: «Goeng si sin sang / Мистер Вампир» (Гонконг 1985), «Genug shut ga chuk / Мистер Вампир 2» (Гонконг 1986), «Ling waan sin sang / Мистер Вампир 3» (Гонконг 1987), «Goeng shut suk suk / Мистер Вампир Сага 4» (Гонконг 1988) и «San goeng shut sin sang / Мистер Вампир 1992» (Гонконг 1992).

1 В даосизме «сянъ» (бессмертные) обретают вечную жизнь и божественные силы (невосприимчивость к огню, способность летать и т.д.), благодаря определенным ритуалам и алхимии. Обычно выделяют три категории сянь: тянъшэнь (небесные бессмертные), которые могут летать; дишэнъ (земные бессмертные), которые живут в горах и лесах; и шищзешэнь (безтелесные бессмертные), которые после смерти оставляют свое тело.

2 Это определение и эти примеры взяты из книги Криса Берри и Мэри Фаркухар(2006, pp. 65-66). Они ссылаются на (Barmé, 1985, pp. 119-120) и (Luo, 1989, pp. 268-269)

3 Хо описывает (Ng Ho, 1989, p. 31) четыре «культурные черты» (или кинематографические условности) в этих фильмах: сохранение трупом «дополнительного дыхания», что приводит к его превращению в вампира; способность человека задержать дыхание, чтобы остановить вампира; превращение жертвы в вампира после того, как вампир высосал ее кровь; и использование деревянных мечей, ниток, обмакнутых в чернила, желтых свитков и клейкого риса для усмирения вампира. 
со злом» визуально представлены через костюмы. В фильмах кризисные тела нечисти и кён-си обычно вписываются в комедию человеческих отношений, часто это игривое соперничество между двумя персонажами мужского пола за внимание или привязанность другого персонажа, например, сифу или красивой женщины. Юмор часто одновременно вербальный и телесный, причем последний подчеркивает зрелищность человеческого тела совершенно иным образом, нежели это происходит в фильмах о боевых искусствах. Боевые сценах в фильмах про кён-си руки и ноги могут демонстрировать физическую силу, ловкость и равновесие, но пах и ягодицы свидетельствуют об уязвимости перед травмами или возбуждением. Телесный комизм как правило рассчитан на мужское зрительское удовольствие ${ }^{1}$. Подобно герою боевых искусств в целом, физическая сила и движения тела сифу наделены «способностью защищать позитивные социальные ценности», что «превращает его победу над злом в подтверждение легитимности системы» (Giukin, 2001, p. 58).

Если сифу усмиряет нечисть и кён-си, появляющихся в моменты кризиса, вопрос заключается в том, как определяются кризисы в этих фильмах. Сюжет фильма «Мистер Вампир», действие которого происходит в республиканском Китае, начинается с того, что мистер Ям нанимает Коу, чтобы тот проконтролировал перезахоронение тела его отца из-за плохого фэн-шуй нынешней могилы ${ }^{2}$. Ям приглашает их обсудить сделку за английским чаем. Боясь ошибиться в этом иностранном обычае, Коу приводит одного из своих учеников, чтобы тот делал все первым. Дочь Яма Тин-тин (Мун Ли Чой-фун) выбирает кофе как возможность проявить свой космополитизм. Поняв, что они не знают тонкостей употребления кофе, она решает подшутить. Отпивая глоток кофе, она запивает его сливками прямо из сливочника и съедает ложку сахара. Двое следуют ее примеру, что очень ее забавляет. В этой сцене представлен шутливый характер фильма, но также - колониальная власть Великобритании над Гонконгом, благодаря одной из самых распространенных практик, поскольку чаепитие часто было средством поддержания чувства национальной идентичности для британских колонистов. Ям - бизнесмен, которому приходится контактировать с иностранцами (европейцами), что, возможно, указывает на британский контроль над несколькими важными портами после Опиумной войны. Майкл Гувер и Лиза Одэм Стоукс предполо-

1 В типичной сцене змея заползает в брюки персонажа-мужчины. Он корчится и кричит, пока змея не выползет через расстегнутую ширинку. Зачастую женские персонажи закрывают глаза, а мужские хватают змею.

2 «Фэн-шуй» буквально означает «ветер, вода» и традиционно символизирует пространство между небом и землей, то есть среду, в которой мы живем. В основе философии лежит то, что мы и наше окружение подпитываемся невидимой, но ощутимой энергией, называемой ци, которая движется как ветер, но может завихряться и задерживаться, как вода и застаиваться; искусство мастера фэн-шуй заключается в определении мест, где ци течет свободно, где она может задерживаться и застаиваться, или где она может быть чрезмерной. Работа заключается в создании пространства для течения ци и активизации возможностей, которые могут быть заблокированы препятствиями - гармоничное восстановление баланса инь и ян, темного и светлого во всех ситуациях. Принципы могут применяться как геофизически, так и на поверхностном уровне для расстановки предметов, дизайна и декора. 
жили, что Яма можно рассматривать как «часть китайской элиты, появившейся в колониальном Гонконге в XIX веке. Они стали успешными торговцами или компрадорами западных фирм, работающих на этой территории» (Hoover \& Stokes, 2002, p. 73). Плохой фэн-шуй, таким образом, можно рассматривать как симптом дисфункции, вызванной общением с иностранцами, соблазнением или порабощением ими.

Джина Марчетти отмечает, что гонконгские фильмы, действие которых происходит в республиканском Китае, а также фильмы, сюжет которых разворачивается во время японской оккупации и гражданских войн до 1949 года, часто иносказательно описывают период 1989-1997 годов (Marchetti, 2006, p. 11). Как и в европейских/голливудских драмах, ошибки в «исторической точности» позволяют представить современные проблемы в диалектике прошлого, настоящего и будущего. Повествование в некоторых фильмах связано с периодом правления династии Цин (1644-1912), в других - республиканского Китая (1912-1949). Сюжет многих фильмов о боевых искусствах как средстве борьбы с кён-си, как ни странно, разворачивается в республиканскую эпоху, когда боевые искусства и истории о нечистой силе были объявлены вне закона как угроза безопасности и модернизации. Образ Китая и усилия по созданию исторической достоверности разнятся от фильма к фильму. Китай больше не разделен, его часто представляют как единую нацию, нередко оккупированную другой нацией. Однако, его также изображают, как нацию, разделенную политически и, в некоторой степени, культурно. Фильмы о кён-си заставляют задуматься об истории, реальной или вымышленной, и вступающей в противоречие с любыми представлениями о едином китайском культурном наследии и национальной идентичности - как маоистской, так и националистической. Вопросы, касающиеся этнических меньшинств и иностранных интервентов в Китае, а также китайских беженцев из Вьетнама в Гонконг, превращаются в контекст, в котором сифу сражается с кён-си. Фильмы, снятые после 1989 года, которые я рассматриваю, представляют Гонконг как место диалога китайских и британских традиций(Roberts, 1998, p. xiv) ${ }^{1}$.

\section{Колонисты уходят, вампиры приходят}

Если роман Стокера «Дракула» затрагивает вопросы «английской» идентичности на ранних этапах глобализации, то фильмы «Вампир против вампира», «Укус любви» и «Доктор Вампир» ставят вопросы об идентичности

1 Начало фильма «Безумное сафари» (Fei zhou han shang, Гонконг, 1990; реж. Билли Чан Пин-иу), например, включает образовательный документальный ролик (возможно, более уместно описать его в соответствии с его функцией как маркетинговый), о различиях между западным вампиром и китайским кён-си, подчеркивая, что культурные различия заметны и узнаваемы. Как и другие «артефакты», украденные при колониализме, кён-си считается чем-то вроде музейного экспоната, достойного продажи на аукционе «китайская мумия», как провозглашают организаторы аукциона, что напоминает термин И. Г. фон Гердера «забальзамированная мумия», применявшийся к Китаю. 
Гонконга в более поздний период этого процесса. В этих фильмах вампиризм в европейском/голливудском стиле перемещается из Лондона в гораздо более экономически прибыльный Гонконг, обращая вспять движение инвестиционного капитала, который к 1990 году начал в больших количествах перетекать из Гонконга в Великобританию. Эти фильмы представляют гонконгскую идентичность как пространство межкультурных контактов между традициями, кодируемыми как китайская и британская, через изображения в фильмах кёнcu, европейского/голливудского вампира и, как показано в одном случае, «смешанного вампира».

В фильме «Вампир против вампира» британский вампиризм проникает в Китай с христианскими миссионерами, а маленький кён-си помогает сифу бороться с европейским/голливудским вампиром. История христианских миссионеров в Китае уходит корнями во времена династии Тан, и она тесно переплетена с договорами между Китаем и европейскими государствами после Опиумных войн (1839-1842 и 1856-1860 гг), согласно которым, помимо прочих неравных привилегий, иностранные подданные выводились из-под юрисдикции китайских судов; последующие соглашения требовали от китайского правительства защиты христианских миссионеров после нападений на них китайских националистов под названием Ихэтуань ( или Ихэцюань, « Кулак во имя праведности и гармонии», называемых британцами «боксерами») в ходе восстаний против иностранного империализма (Roberts, 1998, p. 34,98). Среди большого количества антихристианских публикаций имелся один памфлет, утверждавший, что западные мужчины пьют менструальную кровь западных женщин, что объясняет их «невыносимую вонь» (Roberts, 1998, p. 101). Европейские державы затем использовали факты нападений на миссионеров для получения дополнительных экономических и политических привилегий.

Сценарий фильма «Вампир против вампира», действие которого происходит в республиканском Китае, показывает напряженность отношений между «традиционным» и «иностранным» в Китае. Приглашенный в деревню для диагностики повторяющихся несмотря на «хороший фэн-шуй» «проблем», однобровый священник (Лам) обнаруживает гнездо летучих мышей, свисающих с ветвей погруженного в воду дерева. Летучие мыши символизируют чужое присутствие в деревне, показывая, что Китай уязвим для иностранной заразы, тем более что затопленное дерево находится рядом с заброшенной христианской миссией. В роли настоятельницы - известная певица Мария Кордеро, переехавшая в Гонконг в возрасте десяти лет в середине 1960-х гг. и начавшая карьеру певицы в середине 1980-х гг.. Кордеро родилась в Макао, который, как и Гонконг в 1997 году, официально вернулся в состав КНР в 1999 году в качестве САР. По этническому происхождению Кордеро частично филиппинских, частично китайских кровей, что наглядно демонстрирует глобализацию. 
Макао был «основан» (колонизирован) португальцами в 1557 году и получил название Cidade do Nome de Deus, de Macau, Não há outra mais Leal («Город имени Бога, Макао, и нет более верного») в 1640 году. Хотя Макао был крупным торговым портом между Китаем и Европой, к 1840-м гг. его затмил Гонконг. Эмиграция из колонии в фильме представлена как средство самосохранения. Священник делит прибыль от работы со своими помощниками, Хохом (Сиу-хоу Чин) и Фоном (Фон Лю), объясняя, что они могут использовать ее для «будущей эмиграции в Гуанчжоу». Гуанчжоу - это кантонскоязычная столица провинции Гуандун на юге Китая, прилегающей к Гонконгу, которую англичане, использовавшие порт для ввоза опиума в Китай, называли Кантон. Такой экскурс в историю Макао и Гуанчжоу важен для понимания тематических сдвигов и замещения в фильме гонконгской идентичности. Дальнейшее присутствие европейского/голливудского вампиризма обнаруживается в запертой «комнате для медитаций» в миссии. Пародируются европейские / голливудские кинематографические условности (чеснок, летучие мыши, распятия). Настоятельница интерпретирует чеснок, свисающий с потолочных балок комнаты как средство изгнания призраков.

Вампир из фильма, один из двух погибших священников миссии, позже обнаруживается в могиле полицейскими. В соответствии с традициями гонконгского кинематографа, согласно которым богатство допустимо, но алчность уже приравнивается к глупости, генерал поручает своим людям вести раскопки в поисках «антиквариата». Когда его люди пытаются достать рубин, прикрепленный к закопанному мечу, небо затягивается тучами. Выкапывая меч, они достают и труп священника. Жители деревни хотят сжечь его и выбросить пепел в море для привлечения «удачи» в деревню, но генерал и его девушка забирают тело к себе. Извлекая драгоценный камень из оправы, генерал режется о меч. Кровь капает на труп, тот ее впитывает, начинает дышать и кусает девушку в шею, а его тело напитывается ее кровью. Оживленный вампир покрыт грязью, одет в черный плащ, у него красные глаза и длинные темные волосы, что визуально больше напоминает европейских / голливудских вампиров, чем кён-си. Пытаясь «побороть» вампира, священник обнаруживает, что искусство фашу неэффективно: вампир разрывает талисман на две части. Священника спасает маленький кён-си, что и отражено в англоязычном названии «Вампир против вампира». В отличие от многих европейских/голливудских фильмов о вампирах, особенно фильмов Hammer, в которых вампира уничтожает солнечный свет, в этом фильме он никак не влияет на них. В конце концов, однобровый священник заводит вампира в зыбучие пески.

Фильм «Вампир против вампира» адаптирует и пародирует в противостоянии жанровые клише из местных и зарубежных фильмов, таким образом, он представляет собой транскультурный текст, что приводит в замешательство западных фанатов, некоторые из которых сомневаются в «аутентичности» 
вампира в европейском / голливудском стиле 1 . Фильм не касается истории происхождения вампиризма, подразумевая, что объяснение находится вне фильма. В фильмах цикла «Мистер Вампир» кён-си представляет собой опасный символ китайского прошлого, которое необходимо похоронить, чтобы обеспечить хороший фэн-шуй, однако здесь, напротив, маленький кён-си служит для восстановления связи с ним.

Впрочем, это китайское прошлое является не только культурным, но и самореферентным по отношению к циклу кён-си, в частности, к совсем недавнему прошлому - появлению младенца кён-си в фильме «Мистер Вампир 2» («Goung si ga chuk/Mr. Vampire 2», Гонконг, 1986; реж. Рики Лау Кун-вай) с целью утверждения специфической местной (гонконгской) идентичности и изгнания «вампиризма» британской колонизации и христианского прозелитизма, а также потенциального «вампиризма» передачи власти ${ }^{2}$. Но вместо того, чтобы занять какую-то сторону, фильм, как и «Укус любви» и «Доктор Вампир», критикует как британскую, так и китайскую власть, конструктивно рассуждая о том, что можно извлечь из кризиса неспокойной современности.

В фильме «Укус любви» гонконгская идентичность становится ареной конфликта двух кинематографических антигероев: вампира и босса триады (организованной преступной семьи). Вампир Герцог Ли (Джордж Лам Чи-чун), имя которого отсылает к Кристоферу Ли, сыгравшему графа Дракулу в большинстве фильмов Наmmer о вампирах, - призрак прошлого, романтический антигерой девятнадцатого века. Прикованный к инвалидному креслу босс триады Фун (Норман Цуй Суй-кун) - эгоистичный антигерой ХХ века, готовый пожертвовать жизнью своей сестры Анны (Розамунд Кван Чи-лам), чтобы спасти свою собственную ${ }^{3}$. Вступительные титры демонстрируют анахронизм существования Ли. В то время как Фун и Анна передвигаются по улицам современного Лондона на лимузинах и спортивных автомобилях, Ли едет в запряженной лошадьми повозке к «готическому» замку, типичному для фильмов Hammer. Дизайн костюмов выполнен с учетом кинематографических условностей: на Ли парик из длинных седых волос, белая рубашка с рюшами, черные брюки, черный жилет и черный плащ с высоким воротником и красной подкладкой. Неспособный адаптироваться к изменившемуся за столетия миру, он измучен и одинок. Для выживания ему необходима человеческая кровь, но он не хочет убивать, поэтому берет ее из банка крови. Но кровь, как напоми-

1 «Стоит того!» (комментарий пользователя на «Yi men dao ren/Vampire vs. Vampire»), (“Hong Kong Movie DataBase," 2001)

2 В фильме «Мистер Вампир 2» представлена нуклеарная семья кён-си. Молодая девушка Чиа-чиа подружилась с ребенком кён-си, протянув ему руку, как Эллиотт протянул руку маленькому космическому пришельцу, брошенному другими в фильме «Инопланетянин» («Е.T.: The Extra-Terrestrial», CША, 1982, реж. Стивен Спилберг). Что еще более важно, фильм отмечает прибытие китайских «людей на лодках» из Вьетнама.

3 Главные звезды, Кван и Лам, ассоциируются поклонниками с их работой в «национальном эпосе» «Однажды в Китае» (Гонконг, 1991; реж. Цуй Харк). Розамунд Кван играет тетю И, а Джордж Лам исполняет заглавную композицию. 
нает ему слуга, стоит дорого, а его финансовое положение нестабильно. Он клянется, что не будет кусать людей, потому что это превратит их в вампиров, что нарушает привычные ассоциации вампиров с угрозой общественному здоровью.

Несмотря на свой комедийный характер, «Укус любви» затрагивает темы гражданства и заражения. Фильм раскрывает правовой статус «иностранных» работников в Лондоне, обращая внимание на удостоверение личности Ли. Не все жители Гонконга имели право на получение британского гражданства ${ }^{2}$. До передачи власти консервативные британские политики опасались, что два с половиной миллиона граждан из Гонконга, зависимого от Британии, иммигрируют в Великобританию (Dummett, 2001, p. 120). Маскарад Ли, таким образом, выглядит правдоподобным, хотя и сильно стилизованным ответом на беспокойство по поводу передачи власти. Положение Фуна не менее опасно. Он страдает от недуга или заболевания крови, требующего переливания, но эта кровь нужна и сироте. В местной больнице Ли исцеляет сироту, сделав прямое переливание вампирской крови, способной противостоять человеческим болезням. Альтруистический поступок Ли необратимо ослабляет его силы, так что Фуну удается заманить того в ловушку. Фун отправляет Ли и сироту в Гонконг в ящиках в качестве воздушного груза, якобы являющегося частью контрабандного бизнеса. Чтобы спастись, Ли кусает его, превращая в вампира. Заподозрив, что Фун является носителем вируса ВИЧ/СПИДа, Ли спрашивает Анну, довелось ли ей и ее брату «водиться» с иностранцами.

Коварный Фун говорит сестре, что он изменился и стал «хорошим». Анна родилась 6 июня 1966 года в 6:00 вечера, что делает ее кровь особенной. Если Фун выпьет ее кровь, он станет «королем демонов». Зная о намерениях своего брата, Анна изучает фильм «Ночь страха II» (США 1989; реж. Томми Ли Уоллес), чтобы узнать о методах уничтожения вампиров ${ }^{2}$. Она также штудирует книгу о вампирах, из которой узнает, что ее брат - «смешанный вампир» и что искренние слезы смертельны для таких вампиров. В финальной схватке Анна предлагает свою шею Ли, чтобы он смог одолеть Фуна. После продолжительной борьбы в подземелье оба вампира прорываются сквозь цементный

1 С процессом деколонизации после Второй мировой войны Великобритания проводила политику, позволяющую странам Содружества оставаться «британскими» и в то же время отличающую эти новые независимые государства от Великобритании. Закон о британском гражданстве 1948 года создал три категории, включая граждан Соединенного Королевства и колоний (CUKC), которые позже были разделены на три новые категории, включая ГБЗТ в Законе о британском гражданстве 1981 года. Акт об иммиграции от 1962 года запрещал жителям Гонконга свободно въезжать в Великобританию. Два закона в 1985 и 1986 годах создали еще одну категорию, British Nationals (Overseas) [BN(O)], которая предусматривала консульскую защиту, но не включала право на проживание в Великобритании. В 1987 году была создана категория постоянного жителя Гонконга. После событий 1989 года в Пекине Великобритания предоставила ограниченному числу жителей Гонконга статус британского гражданина (БГ) с правом проживания в Великобритании, а также статус БГ некитайским этническим меньшинствам, проживающим в Гонконге (Ai, 2002).

2 В фильме «Ночь страха» старшеклассник Чарли успешно распознает в своем соседе Джерри вампира благодаря регулярному просмотру старых фильмов по телевизору. Он обращается за помощью к ведущему телешоу, который во многих фильмах играет роль охотника на вампиров. 
потолок на солнечный свет, где их тела взрываются. Благодаря самоотверженному акту самоуничтожения Ли, Анна и сирота не превращаются в вампиров. Они могут жить как люди, как незараженные жители Гонконга. Фильм заканчивается тем, что вампирский наряд Ли начинает светиться белым светом. Анна находит младенца, который, как ей говорят, и есть Ли. Ее искренние слезы освободили его от вечной вампирской жизни и вернули в цикл реинкарнации в качестве человека (этнически китайца). Как и Фун, Ли был «смешанным вампиром», амбивалентной метафорой для гонконгцев, либо «зараженных», либо покинутых своими колониальными правителями, что указывает на продолжающиеся переговоры и споры внутри «кризисных тел» Гонконга.

В «Докторе Вампире» заражение крови ассоциируется с культурной или национальной идентичностью. Находясь в Великобритании по делам, гонконгский доктор Чан Та-цун (Боуи Лам) заходит в бар, где женщины-вампиры сосут кровь у своих жертв-мужчин, а затем позволяют своему белому хозяинувампиру, Графу (Питер Кьер), высасывать эту кровь из их шей. Кровь здесь иллюстрирует концепцию Маркса о товарном фетишизме, поскольку Граф отказывается выполнять работу по заманиванию или соблазнению жертв для получения крови. Порабощение графом женщин наводит на мысль о «вампирской» эксплуатации человеческого труда капитализмом. В баре Чан видит китайскую женщину, которая, по его мнению, подвергается нападению со стороны белого мужчины. «Ты издеваешься над китайцами», - кричит Чан на белого мужчину, поворачиваясь, чтобы сказать женщине: «Британцы всегда плохо обращались с китайцами». Женщина, Элис (Эллен Чань), на самом деле вампир, а мужчина - ее жертва. Элис отводит Чана в отдельную комнату, где пьет его кровь и заражает. Когда Граф пьет кровь своих рабов, он испытывает отвращение, пока не пробует кровь Чана, которая теперь течет в венах Алисы. «Эта кровь похожа на китайский женьшень», - говорит он, после чего бьет ее по голове, бросает в огонь даосский амулет, который дал ей Чан, и приказывает отправиться в Гонконг за новой кровью со вкусом женьшеня. Согласно на первый взгляд антиколониальной структуре повествования фильма, через кровь происходит заражение китайцев, но она является и питанием для британцев.

Комедия фильма построена на межкультурных и интертекстуальных шутках о вампиризме и колониализме. Невеста Чана, медсестра Мэй Чен (Шейла Чан), празднует его возвращение супом из женьшеня и креветками с чесноком. Вкус чеснока вызывает у него отвращение, как, вероятно, и у европейских/голливудских вампиров. По иронии судьбы, основное блюдо Мэй, суп из женьшеня, - это то, что делает кровь Чана такой аппетитной для Графа. Превращение Чана в вампира неоднозначно, как у персонажа Николаса Кейджа в фильме «Поцелуй вампира» (США, 1989; реж. Роберт Бирман) ${ }^{1}$.

1 Стефан Хаммонд и Майк Уилкин отмечают эту интертекстуальную ссылку: «Вернувшись в Гонконг, док обнаруживает, что потерял интерес к креветкам с чесноком и начинает ходить в солнцезащитных очках и 
Чан начинает верить, что солнечный свет вредит его глазам. Во время шопинга с Мэй он покупает пару солнцезащитных очков, а также смокинг и длинный плащ. За пределами больницы он размахивает своим новым плащом, пародируя аналогичные жесты в голливудских фильмах о вампирах, начиная с «Дракулы» (США, 1931; реж. Тод Браунинг). Он пьет овощной (в основном томатный) сок марки V8 через две соломинки, держа их во рту так, что они похожи на удлиненные клыки вампира. В отличие от героя Кейджа, Чан обретает сверхъестественную способность телепатически влиять на движения других людей. Когда он начинает сомневаться, может ли он быть кён-си («вампиром» в субтитрах), он прыгает с вытянутыми руками, чтобы определить, чувствует ли он себя естественно, когда «ходит» как кён-си. Позже его коллеги дарят ему наряд, похожий на те, что носят кён-си в фильмах. Кризис идентичности Чана визуально представлен через костюмы и реквизит, в частности, черный плащ из фильма о вампирах и халат кён-си. Он проявляется в комедийном смешении кинематографических традиций изображения европейских/голливудских вампиров и гонконгских кён-си. Боязнь заражения, будь то «английский грипп» (инверсия «азиатского гриппа») или ВИЧ-СПИД, еще один источник шуток в фильме, которые содержат социальную критику в кинематографических и культурных стереотипах 1 . Хотя заражение крови потенциально смертельно, кинематографические конвенции приписывают ему и омолаживающий эффект.

Фильм заканчивается противостоянием Графа и гонконгцев. Приехавшая в Гонконг, чтобы спасти Чана, Алиса оказывается на стороне китайских персонажей против своего иностранного хозяина. «Вернись ко мне», - требует Граф на английском языке. Она отвечает, также на английском: «Мы разные». Заявление Алисы подчеркивает культурное различие: находящийся за границей китаец не «такой же», как британец, не «такой же», как другие (белые) рабы.

Хотелось бы расширить этот анализ дальше. На менее буквальном уровне, если историческая колониальная власть (Великобритания) является заменой потенциальной новой колониальной власти (КНР), заявление Алисы также выражает ее отличие от других китайцев. Гонконгские китайцы «не такие же», как китайцы КНР. Порядок и идентичность возрождаются таким образом, что на первый план выходит китайская культура, существовавшая до «унижения национального самосознания» времен Опиумных войн, когда Гонконг был отнят Великобританией. Особенно это проявляется в «силе

эдвардианском плаще, как Николас Кейдж в фильме «Поцелуй вампира»(Hammond \& Wilkins, 1996, p. 90).

1 По возвращении в Гонконг Чан хвастается перед своими коллегами, что он «сделал это» в Англии и теперь «настоящий мужчина». Коллеги шутят, что он, должно быть, переспал с (британской) проституткой, но Чан настаивает, что он спал с «красивой китаянкой». Позднее они понимают, что следы укусов Алисы на гениталиях Чана являются источником заражения. Когда они встречают Алису, один из коллег Чана защищается распятием, но она отвечает, что распятия «вышли из моды» и не имеют никакого эффекта. Более того, она бы и не стала пить его кровь, потому что он «спит с кем попало», и его кровь может быть заражена СПИДом. Когда пациентка-ипохондрик жалуется на плохое самочувствие после алкогольной ночи, врачи решают, что ей нужно сдать анализ крови на «английский грипп». Взяв образцы ее крови, они отдают их Чану и Алисе в качестве питания. 
Будды», когда перед нами возникает традиционное китайское оперное представление (или церемония призраков), в рамках сюжета работающая на сбор средств для больницы, и предвосхищающая создание КНР или КР как современного китайского национального государства. По мере демонстрации боевых искусств персонажами в традиционных оперных костюмах, из третьего глаза статуи Будды исходит луч света ${ }^{1}$. Затем Чан и его друзья-врачи используют фашу, чтобы направить свет на Графа и Алису. Будда освещает Графа, который взрывается, а зараженные китайцы исцеляются. Даже больше, чем в случае с ребенком кён-си в фильме «Вампир против вампира», гонконгская идентичность защищена традиционной китайской культурой от иностранного заражения, утрированно представленного как вампиризм/христианство. Однако под иностранным заражением может также скрываться страх перед передачей власти.

Картина шутливо критикует капиталистическую систему Гонконга. Управляющий больницей изображен как человек, больше заботящийся о прибыли, чем о здоровье своих пациентов. Чан и двое его коллег неоднократно защищают свои должности, отмечая, что три врача более эффективны. Более того, они проводят ряд фиктивных операций, включая обрезание, лидеру триады, чтобы принести прибыль больнице. B XIX в. триады были привержены идее свержения Цин и восстановления Мин, но в мирное время, например, в эпоху ранней республики, они больше ассоциировались с организованной преступностью (контрабанда и рэкет) (Roberts, 1998, p. 48). Традиционная китайская культура тоже коммерциализируется: опера нужна, чтобы собрать средства для больницы, а сифу предлагает свои знания любому, кто заплатит, что, возможно, наводит на мысль о капиталистическом «компромиссе». Таким образом, фильм представляет собой вызов культурному эссенциализму: Гонконгцы не являются китайцами в понимании британского колониализма и не являются китайцами в понимании китайского национализма. Эти три фильма рисуют кризис как телесный, показывая материальные последствия уже произошедших и грядущих преобразований Гонконга с 1980-х гг..

\section{Заключение - материализация и сплав}

От национальной «открытости» незримого голливудского стиля до радикальной перестройки его логики Третьим кино, кинематограф - это искусный инструмент для представления, производства и распространения пластичных форм национальной культуры и средство для формирования национального самосознания. Фильмы сами по себе являются удивительно гибридным средством и формой культурного выражения со сложной и неравномерной историей колонизации аудитории, а также сопротивления или противостояния колонизационным процессам. Хоть камеры и склонны к западной одноточечной композиционной перспективе, однако линзы и расстояния между

1 В Китай буддизм попадает из Индии. 
объектом и объективом могут адаптировать перспективу камеры для приближения к другим эстетическим традициям ${ }^{1}$ Такие различия, согласно традиционной эстетике, неизбежно рискуют эссенциализировать и онтологизировать культуру и игнорировать капризы зрительской аудитории, но они предлагают и понимание различных культурных способов использования кинематографических конвенций, а также культурных концепций кино. Так как первые кинематографисты в Китае были иностранцы, в основном европейцы, китайские кинематографисты научились использовать западные кинематографические техники, чтобы подчеркнуть стилизованное действие, эстетизацию движений тела в гонконгском кино (Yung, 2005, р. 29). Докинематографические традиции создали основу для «отличительной манеры китайского кино», и особенно это справедливо для оперы. Кино-опера была «китайской разновидностью «киноаттракциона» (Berry \& Farquhar, 2006, p. 47). Иными словами, транскультурное значение зачастую бывает сложным и противоречивым.

Когда цикл о кён-си подошел к логическому концу, режиссер «Мистера Вампира» Рики Лау снял картину «Романтика вампиров» (1994). В этой картине использованы различные кинематографические условности, характерные для местных фильмов третьей категории (т.е. включающих насилие и эротику), что составляли почти половину гонконгской продукции в начале 1990-х годов, и даже для голливудской «Красотка» (США 1990; реж. Гэрри Маршалл). В этом фильме китайские актеры изображают вампиров в европейском / голливудском стиле. Транскультурность - как в терминах китайского и американского / британского, так и в смысле вампиризма и кён-си - больше не обозначается и не представляется как нечто определенное, различимое. Транскультурность это, попросту говоря, отражение жизненных реалий. Липкий рис, важный реквизит в фильмах «Мистер Вампир», является такой же частью мизансцены, как и KFC («Ресторан быстрого питания Кентукки», согласно субтитрам), что напоминает амбивалентность знаменитого сопоставления Маркса и кокаколы у франко-швейцарского режиссера Жан-Люка Годара. Противоречий много. Глобальная культура - это сплошные противоречия. Хотя фильм «Романтика вампиров» был успешнее, чем «Доктор Вампир», он нашел лишь ограниченную аудиторию как в Гонконге, так и в Северной Америке, возможно, из-за относительного отсутствия концентрированной национальной идентичности, выраженной в транскультурной формуле. В недавнем фильме о кён-си «Эпоха вампиров/Охотники на вампиров» Цуя Харка (Гонконг-Япония-Нидер-

1 Кадрирование и монтаж создают альтернативную эстетику, так что южноазиатские популярные фильмы опираются на санскритскую эстетику, подчеркивающую формы аффекта, в дополнение к колониальным следам аристотелевской эстетики, ценящей единство и повествование. Африканские фильмы часто отказываются от колониальных пережитков линейной хронологии западного кино, которая слишком упрощена и косна для выражения коллективных хронотопов. Некоторые фильмы Юго-Восточной Азии опускают сцены драматического действия, на которых основывается весь смысл западного кино. Западные зрители часто жаловались, что в гонконгских боевиках хореография превалирует над связностью и логикой повествования, хотя, как это ни парадоксально, зрители часто смотрят эти фильмы именно ради этих динамичных сцен. 
ланды 2002; реж. Уэлсон Чин) комедия почти полностью отсутствует, что побудило пользователей IMDb написать, что фильм делает с кён-си то же, что «Крадущийся тигр, затаившийся дракон» сделал с уся: голливудизирует его. Действие фильма происходит в период цинского расцвета, а не падения Мин или Цин, или позднего республиканского периода, что позволяет предположить, что кризис был отложен, если не предотвращен, еще раз. «Классический» кён-си, освобожденный от комедии, получил новое воплощение.

\section{Список литературы / References}

Abbas, A. (1997). Hong Kong: Culture and the Politics of Disappearance. Minneapolis: University of Minnesota Press.

Ai, M. (2002, August). The Transition of Hong Kong People's Nationality after World War II. Retrieved January 16, 2007, from E-Journal on Hong Kong Cultural and Social Studies 2 website: https://hku.hk/hkcsp/ccex/ehkcss01/issue2_ar ma_01.htm

Ansen, D. (1996, February 19). Movies: Chinese Takeout. Newsweek.

Aronowitz, S., Arrighi, G., Brennan, T., Bull, M., Callinicos, A., Gindin, S., ... Wood, E. M. (2003). Debating Empire (G. Balakrishnan, Ed.). London; New York: Verso.

Barmé, G. R. (1985). Persistance de la tradition au royaume des ombres: Quelques notes visant à contribuer à une approache nouvelle du cinéma chinois, chapter in Le Cinéma chinois (M.-C. Quiquemelle, Ed.). Paris: Centre Georges Pompidou.

Berry, C., \& Farquhar, M. A. (2006). China on Screen: Cinema and Nation. New York: Columbia University Press.

Bordwell, D. (2000). Planet Hong Kong: Popular cinema and the art of entertainment. Cambridge, Mass: Harvard University Press.

Chan, N. S.-H. (2000). Rewriting History: Hong Kong Nostalgia Cinema and Its Social Practice.

In P. Fu \& D. Desser (Eds.), The Cinema of Hong Kong: History, arts, identity. Cambridge, UK; New York, NY: Cambridge University Press.

Cheung, E. M. K., \& Chu, Y. (2004). Introduction: Between Home and World. In E. M. K. Cheung \& Y. Chu (Eds.), Between Home and World: A Reader in Hong Kong Cinema. Hong Kong, China: Oxford University Press.

Chow, R. (1994). Primitive Passions: Visuality, Sexuality, Ethnography, and Contemporary Chinese Cinema. New York: Columbia University Press.

Chu, Y. (2004). Introduction: Globalization and the Hong Kong Film Industry. In E. M. K. Cheung \& Y. Chu (Eds.), Between Home and World: A Reader in Hong Kong Cinema. Hong Kong, China: Oxford University Press.

Ciecko, A. T. (2005). Introduction to Popular Asian Cinema. In A. T. Ciecko (Ed.), Contemporary Asian Cinema: Popular Culture in a Global Frame. New York and Oxford: Berg Publishers.

Dai, J. H. (2002). Postcolonialism and Chinese Cinema in the Nineties. In J. Wang \& T. E. Barlow (Eds.), \& H. H. Kuoshu (Trans.), Cinema and desire: Feminist Marxism and cultural politics in the work of Dai Jinhua. London New York: Verso.

Dai, J. H. (2005). Order/Anti-order: Representation of Identity in Hong Kong Action Movies. In M. Morris, S. L. Li, \& S. C. Ching-Kiu (Eds.), \& J. Zhang (Trans.), Hong Kong Connections: 
Transnational Imagination in Action Cinema. Durham: Hong Kong: Duke University Press Books.

Dannen, F., \& Long, B. (1997). Hong Kong Babylon: An insider's guide to the Hollywood of the East. New York: Hyperion/ Miramax.

Dummett, M. (2001). On immigration and refugees. London; New York: Routledge.

Fu, P., \& Desser, D. (Eds.). (2000). The Cinema of Hong Kong: History, arts, identity. Cambridge, UK; New York, NY: Cambridge University Press.

Giukin, L. (2001). Boy-Girls: Gender, Body, and Popular Culture in Hong Kong Action Movies. In M. Pomerance (Ed.), Ladies and Gentlemen, Boys and Girls: Gender in Film at the End of the Twentieth Century. Albany: State University of NY Press.

Gomery, D. (2005). The Hollywood studio system: A history. London: BFI Publ.

Hammond, S., \& Wilkins, M. (1996). Sex and Zen \& A Bullet in the Head. New York: Simon \& Schuster.

Hardt, M., \& Negri, A. (2000). Empire. Cambridge, Mass.: Harvard University Press.

Hardt, M., \& Negri, A. (2004). Multitude: War and Democracy in the Age of Empire. New York, NY: Penguin Books.

Hong Kong Movie DataBase. (2001, February 20). Retrieved December 14, 2002, from Hong Kong Movie DataBase website: https://hkmdb.com/

Hoover, M., \& Stokes, L. O. (2002). At the Hong Kong Hop: Mr. Vampire Spawns Bloodsucking Genre. Paradoxa, (17), 68-76.

Hutchings, P. (2001). Terence Fisher. New York: Manchester University Press.

Li Cheuk-to. (1989). Introduction. In Li Cheuk-to (Ed.), Phantoms of the Hong Kong Cinema. Hong Kong: The Urban Council of Hong Kong.

Li, S. L. (2001). Kung fu: Negotiating nationalism and modernity. Cultural Studies, 15(3-4), 515-542. doi: 10.1080/095023800110046687

Lo, K. (2001). Transnationalization of the Local in Hong Kong Cinema of the 1990s. In E. C. M. Yau (Ed.), At Full Speed (pp. 261-276). University of Minnesota Press.

Logan, B. (1996). Hong Kong action cinema. Woodstock, N.Y: Overlook Press.

Lu, H. (Ed.). (1997). Transnational Chinese cinemas: Identity, nationhood, gender. Honolulu, HI: University of Hawaii Press.

Luo, Y. (1989). A Preliminary Discussion of National Style in Film [in Chinese]. In Y. Luo, P. Li, \& H. Xu (Eds.), Anthology of Chinese Film Theory (Vol. 1). Beijing: Wen hua yi shu chu ban she.

Marchetti, G. (1998). Introduction: Plural and Transnational. Jump Cut, 42, 68-72.

Marchetti, G. (2006). From Tian'anmen to Times Square: Transnational China and the Chinese Diaspora on Global Screens, 1989-1997. Philadelphia: Temple University Press.

Marx, K. (1977). Capital: A Critique of Political Economy (B. Fowkes, Trans.). New York: Vintage.

Moretti, F. (1988). Signs Taken for Wonders: Essays in the Sociology of Literary Forms (D. Fischer, D. Forgacs, \& D. Miller, Trans.). London; New York: Verso.

Morris, M. (2005). Introduction: In M. Morris, S. L. Li, \& S. C. Ching-kiu (Eds.), Hong Kong Connections (pp. 1-18). Hong Kong University Press.

Newman, K. (1993, January). Bloodlines. Sight and Sound. 
Ng Ho. (1989). Abracadaver: Cross-Cultural Influences in Hong Kong Vampire Movies. In C. Li (Ed.), Phantoms of the Hong Kong Cinema. Hong Kong: The Urban Council of Hong Kong.

Pile, S. (2003). Perpetual Returns: Vampires and the Ever-Colonized City. In R. Bishop, W. W. Yeo, \& J. Phillips (Eds.), Postcolonial Urbanism: Southeast Asian Cities and Global Processes. Routledge.

Roberts, J. A. G. (1998). Modern China: An Illustrated History. Stroud, Gloucestershire: The History Press.

Rofel, L. (2001). Discrepant modernities and their discontents. Positions: East Asia Cultures Critique, 9(3), 637-649. doi: 10.1215/10679847-9-3-637

Sassen, S. (1991). The Global City: New York, London, Tokyo. Princeton, N.J: Princeton University Press.

Stam, R. (2003). Beyond Third Cinema: The Aesthetics of Hybridity. In A. R. Gunerante \& W. Dissanayake (Eds.), Rethinking Third Cinema. New York and Oxford: Routledge.

Stokes, L. O., \& Hoover, M. (2000). City on fire: Hong Kong cinema. London; New York: Verso.

Teo, S. (1989). In the Realm of Pu Songling. In Li Cheuk-to (Ed.), Phantoms of the Hong Kong Cinema. Hong Kong: The Urban Council of Hong Kong.

Teo, S. (1997). Ghost, Cadavers, Demons, and Other Hybrids. In Hong Kong Cinema: The Extra Dimension. London: British Film Institute.

Teo, S. (2000). Local and Global Identity: Whither Hong Kong Cinema? Retrieved March 22, 2003, from Sense of Cinema online website: http://senseofcinema.com/contents/00/7/hongkong.html

Teo, S. (2002). The Legacy of T. E. Lawrence: The Forward Policy of Western Film Critics in the Far East. In A. L. Williams (Ed.), Film and nationalism (pp. 181-194). New Brunswick, N.J.: Rutgers University Press.

Thomas, R. (1985). Indian Cinema: Pleasures and Popularity. Screen, 26(3-4), 116-131. doi: 10.1093/ screen/26.3-4.116

Vié, C. (1996). Jiang shi. In K. Newman (Ed.), The BFI Companion to Horror. London: British Film Institute.

Wilson, K. M. (1998). The History of the Word Vampire. In A. Dundes (Ed.), The Vampire: A Casebook. Madison: University of. Wisconsin Press.

Yang, J. (2003). Once upon a time in China: A guide to Hong Kong, Taiwanese, and mainland Chinese cinema. New York: Atria Books.

Yau, C.-M. E. (Ed.). (2001). At full speed: Hong Kong cinema in a borderless world. Minneapolis: University of Minnesota Press.

Yau, K. S. (2005). Interactions Between Japanese and Hong Kong Action Cinemas. In M. Morris, S. L. Li, \& Chan Stephen Ching-kiu (Eds.), Hong Kong Connections (pp. 35-48). Hong Kong University Press.

Yung, S. (2005). Moving Body: In M. Morris, S. L. Li, \& S. C. Ching-kiu (Eds.), Hong Kong Connections (pp. 21-34). Hong Kong University Press.

Zhang, Y. (2002). Screening China: Critical interventions, cinematic reconfigurations, and the transnational imaginary in contemporary Chinese cinema. Ann Arbor, Mich: Center for Chinese Studies. 